\title{
RADIOCARBON ANALYSIS CONFIRMS THE ANNUAL NATURE OF SAGEBRUSH GROWTH RINGS
}

\author{
Franco Biondi ${ }^{1} \bullet$ Scotty D J Strachan $^{2} \bullet$ Scott Mensing $^{3} \bullet$ Gianluca Piovesan ${ }^{4}$
}

ABSTRACT. In the Great Basin of North America, big sagebrush (Artemisia tridentata Nutt.) growth rings can be used to reconstruct environmental changes with annual resolution in areas where there is otherwise little such information available. We tested the annual nature of big sagebrush wood layers using accelerator mass spectrometry (AMS) radiocarbon dating. Four cross-sections from 3 sagebrush plants were collected near Ely, Nevada, USA, and analyzed using dendrochronological methods. Ten ${ }^{14} \mathrm{C}$ measurements were then used to trace the location of the 1963-64 "bomb spike." Although the number of rings on each section did not exceed 60, crossdating was possible within a section and between sections. Years assigned to individual wood layers by means of crossdating aligned with their expected ${ }^{14} \mathrm{C}$ values, matching the location of the ${ }^{14} \mathrm{C}$ peak. This result confirmed the annual nature of growth rings formed by big sagebrush, and will facilitate the development of spatially explicit, well-replicated proxy records of environmental change, such as wildfire regimes, in Great Basin valleys.

\section{INTRODUCTION}

Conservation and restoration of natural landscapes is guided by the determination of ecological reference conditions (Egan and Howell 2001). In the Great Basin of North America, land management agencies have a paucity of long-term information on ecosystem dynamics and their driving forces, such as wildfire. Detailed and reliable archival records of fire occurrence are limited to the past 20 to $30 \mathrm{yr}$ (Westerling et al. 2003, 2006), hence they do not allow the identification of fire regime or of fire-climate relationships prior to Euro-American settlement. Dendrochronological analysis of fire-scarred trees can provide fire history information at a range of spatial scales and over several centuries, down to the actual year or season (Swetnam et al. 1999). In the Great Basin, most valleys are occupied by semi-arid shrublands, and there is no direct evidence of fire history for this landscape element (Blackburn and Tueller 1970). Knowledge of fire history in sagebrush (Artemisia sp.) steppe ecosystems comes almost entirely from fire-scar studies of conifers growing nearby or in association (Houston 1973; Burkhardt and Tisdale 1976; Gruell 1999; Miller and Tausch 2001). Existing fire history records for Great Basin woodlands and shrublands, however, are fragmentary, and hence, inconclusive (Paysen et al. 2000). For example, while some studies demonstrate a fire regime shift over the past century in pinyon-juniper woodlands (Miller and Rose 1999), others do not (Floyd et al. 2000), and a recent review suggests there is insufficient evidence that reduced fire frequency has led to tree invasion of sagebrush communities (Baker and Shinneman 2004). Pre-settlement fire history in sagebrush-dominated environments has also been reconstructed using macroscopic charcoal analysis from spring and lake sediments (Mensing et al. 2006), but this method lacks the temporal resolution of dendrochronological analysis. Overall, information on fire regime (including frequency, return interval, area burned, etc.) in the Great Basin during pre-settlement times is not currently available on spatial and temporal scales that can effectively be used for determining landscape processes.

A potential source of information on fire regime in sagebrush ecosystems is provided by the age of existing individuals. Because wildfire is predominantly a stand-replacing phenomenon in this vegetation type, maximum plant age provides a terminus post quem for fire occurrence. In other words, fire is regarded as absent from the study area for at least as many years as the maximum plant age.

\footnotetext{
${ }^{1}$ DendroLab, Department of Geography, and Graduate Program of Hydrologic Sciences, University of Nevada, Reno, Nevada 89557, USA. Corresponding author. Email: fbiondi@ unr.edu.

${ }^{2}$ DendroLab, Department of Geography, University of Nevada, Reno, Nevada 89557, USA.

${ }^{3}$ Department of Geography, University of Nevada, Reno, Nevada 89557, USA.

${ }^{4}$ Department of Environment and Forests, University of Tuscia, Viterbo, Italy.
} 


\section{$1232 \quad$ F Biondi et al.}

There are several reasons why fire could have been absent for a longer time, from delayed plant regeneration after fire to factors unrelated to wildfire (e.g. senescence, grazing, human disturbance) that cause mortality of old individuals. Nonetheless, when analyzed in detail over a large area, age structure of sagebrush in Great Basin valleys should provide information on long-term patterns of landscape disturbance that would not otherwise be available.

Among sagebrush ecosystems, big sagebrush (Artemisia tridentata Nutt.) steppe communities occupy over 60M ha from Baja California and northern Arizona all the way to the Pacific Northwest and the Dakotas (Figure 1) (Little Jr 1976). Many associated species of plants and animals are of environmental concern because of declining habitats or populations (Wisdom et al. 2003). The taxonomy of big sagebrush is complex, with at least 5 subspecies (Cronquist et al. 1994; West and Young 2000), i.e. basin big sagebrush (ssp. tridentata), Wyoming big sagebrush (ssp. wyomingensis Beetle and Young), mountain big sagebrush (ssp. vaseyana [Rydb.] Beetle), xeric big sagebrush (ssp. xericensis Winward ex R. Rosentreter and R. Kelsey), and California big sagebrush (ssp. parishii A. Gray). Some authors also recognize a 6th subspecies (Wambolt and Frisina 2002), i.e. subalpine big sagebrush (ssp. spiciformis [Osterhout] Kartesz and Gandhi), while others distinguish 3 subspecies (tridentata, wyomingensis, and vaseyana), plus 3 forms of the subspecies vaseyana (Shumar et al. 1982). Because the variability in morphology makes subspecies and forms difficult to separate in the field (West et al. 1978), especially considering the possibility of hybridization, for dating purposes we refer to big sagebrush (Artemisia tridentata Nutt.) without further specification.

The first extensive study of wood rings in big sagebrush was conducted by Ferguson (1964), who reported a maximum age of $217 \mathrm{yr}$. Using extensive sample collections from the central and southern portion of its geographical range, he concluded that "no instance of the complete absence of a seasonal growth ring has been found" (Ferguson 1964:16). On the other hand, he mentioned that false rings, sometimes more than 1 per year, could be formed in southern areas. Near the northwest limit of big sagebrush distribution, Cawker (1980) reported occasional false and locally absent rings in another very large collection of 1276 sections. Age of big sagebrush was well correlated with maximum basal stem diameter in Wyoming (Perryman and Olson 2000), where maximum age was $81 \mathrm{yr}$ (Perryman et al. 2001). No prior studies ever questioned the annual nature of big sagebrush growth rings, possibly because the seasonal development of its leaves has long been documented (Diettert 1938). While crossdating is indeed a powerful tool to assign calendar dates to annual wood increments, additional, independent verification should be attempted when dealing with species that either do not form clearly visible rings (such as many tropical species), grow in highly stressed environments (so that many growth layers can be locally missing), or experience more than 1 growing period during the year (so that many false rings could be formed). Since the most extensive studies of big sagebrush growth rings (i.e. Ferguson 1964; Cawker 1980) did not independently verify their annual nature, and did not include samples from Nevada, we checked the annual nature of sagebrush wood layers by means of "bomb" radiocarbon dating.

${ }^{14} \mathrm{C}$ analysis can be used to date modern (i.e. post-1950) organic materials (Bowman 1990). During the Cold War period, aboveground nuclear tests practically doubled the ${ }^{14} \mathrm{C}$ level in the troposphere. Following nuclear non-proliferation treaties in the 1960 s, amounts of ${ }^{14} \mathrm{C}$ at the Earth's surface declined continuously and are now returning to background levels (Hua and Barbetti 2004). This pronounced spike in ${ }^{14} \mathrm{C}$ amounts, beginning with a sharp increase in the 1950s, peaking in 1964 at most Northern Hemisphere locations, and tapering off since then, provides an unequivocal signature that can be traced for dating organic material. This method has been applied to a number of research topics, from estimating the growth rate of calcareous algae (Frantz et al. 2000) to determining gap dynamics in tropical forests (Horvitz and Sternberg 1999). More relevant to tree-ring science, accel- 


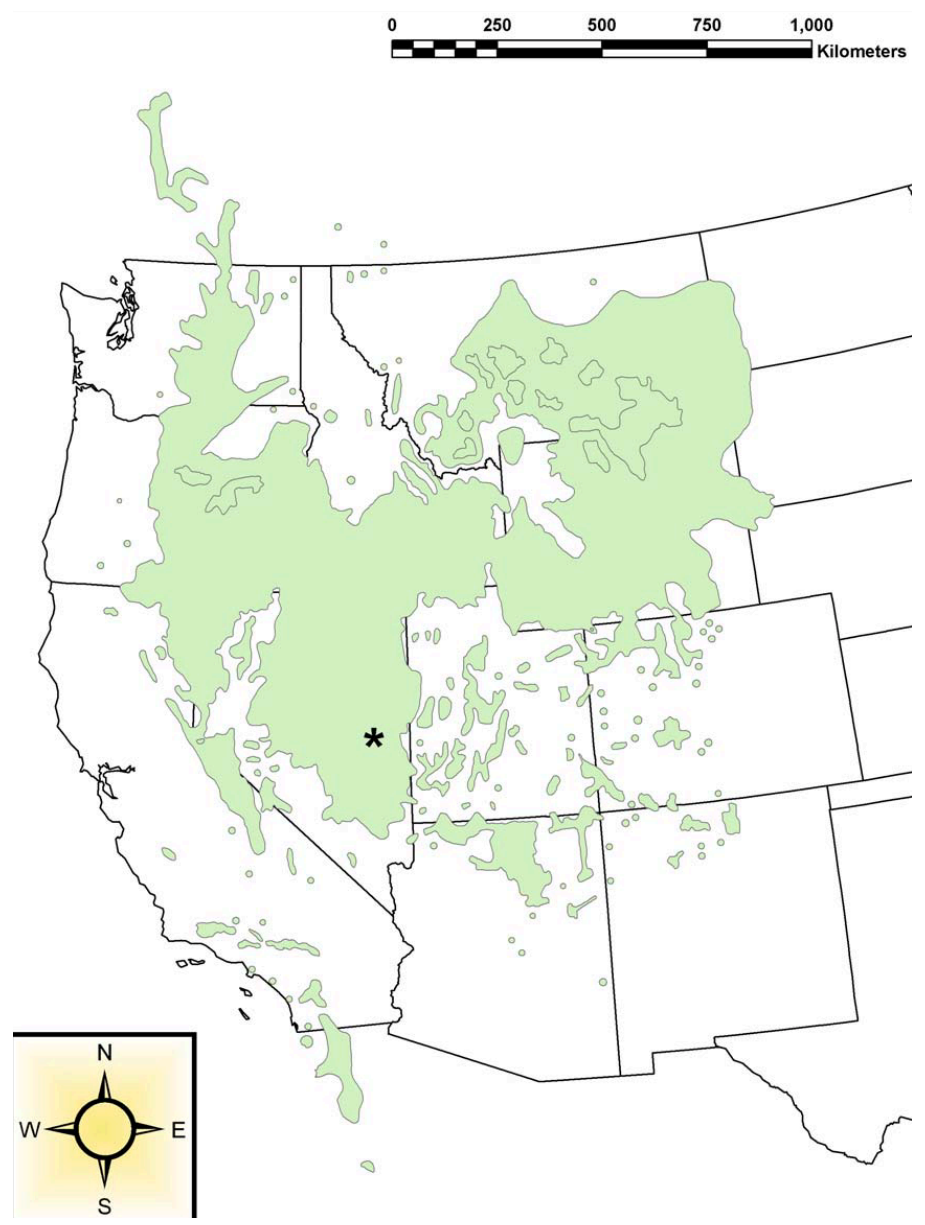

Figure 1 Distribution of big sagebrush (Artemisia tridentata Nutt.) in North America, with location of the study area (asterisk).

erator mass spectrometry (AMS) ${ }^{14} \mathrm{C}$ analysis was employed to test the annual nature of xylem layers in subtropical trees that could not be crossdated (Biondi and Fessenden 1999), or to verify growth years assigned using stable isotopic values in tropical species (Poussart et al. 2004). In general, when tree growth increments have unclear boundaries but vary in size from one year to the next, accurate dating can only be obtained by combining ${ }^{14} \mathrm{C}$ dating with macro- and microscopic descriptions of the wood and its layers (Worbes and Junk 1989; Dezzeo et al. 2003). In this paper, we used a combination of dendrochronological crossdating and ${ }^{14} \mathrm{C}$ AMS analysis to answer the question, "Are growth rings of Artemisia tridentata truly annual?" The answer to this question has immediate implications for the broader issue of reconstructing environmental changes in semi-arid shrublands.

\section{MATERIALS AND METHODS}

\section{Field Sampling and Dendrochronological Analysis}

Four sections were cut using a chainsaw from 3 separate individuals ( 1 had a double stem), at a site located near Ely, Nevada, USA $\left(39.30^{\circ} \mathrm{N}, 114.99^{\circ} \mathrm{W} ; 2070 \mathrm{~m}\right.$ asl; see Figure 1). No evidence of prior disturbance was noted at this site, where several individuals had sizable stems $(>10 \mathrm{~cm}$ base 
diameter, $>1 \mathrm{~m}$ height). Mature dominants typically have a single, multi-branched stem (Ferguson 1964), and samples were collected near the base of each plant's short main trunk. After transportation to the University of Nevada DendroLab, the sagebrush sections were sanded and polished using a belt sander and progressively finer sandpaper, until individual wood cells were clearly visible under a binocular microscope with 10 to 50× magnification (Ferguson 1964). Calendar dates were assigned to growth rings by means of visual crossdating, performed using skeleton plots (Stokes and Smiley 1996).

Samples were sent for ${ }^{14} \mathrm{C}$ analysis to the National Ocean Sciences AMS (NOSAMS) facility at Woods Hole Oceanographic Institution. Five samples from each of 2 sagebrush cross-sections, corresponding to the estimated years $1955,1962,1964,1966$, and 1975, were manually collected by carefully separating individual growth layers in the tangential direction. Each of these 10 samples was air-dried and weighed. Because NOSAMS required a minimum of $300 \mu \mathrm{g} \mathrm{C}$ for each sample and the amount of $C$ was estimated to be 30-50\% of the measured wood weight (Rowell 1984), individual sample collection usually ended after reaching about $1 \mathrm{~g}$ of material. Sample identification codes were assigned without reference to calendar years or location in the cross-section. By doing so, we guaranteed that the ${ }^{14} \mathrm{C}$ analysis, which was performed in a different laboratory, could not be influenced by prior knowledge on the chronological sequence of the samples.

After the samples were sent to NOSAMS, all radii that had been skeleton plotted were measured. Annual increments were measured perpendicularly to the ring boundaries and with $0.001-\mathrm{mm}$ resolution using a Velmex sliding stage interfaced with a video camera mounted on a 14 to $90 \times$ stereozoom binocular microscope. Ring-width series were quality controlled both visually, by generating time-series plots and looking for outliers, and numerically, by means of task-specific software (Holmes 1983; Grissino-Mayer 1997). Crossdating within a section and among all radii was quantified for all series $\geq 48 \mathrm{yr}$ by the average of Pearson's correlation coefficients (Wigley et al. 1984), by the average of Baillie-Pilcher's $t$ values (Baillie and Pilcher 1973), by the average percentage of agreement coefficient or GLK for "Gleichläufigkeit" (Eckstein and Bauch 1969), and by the first principal components (Jolliffe 1986) of ring-width series for the 1956-2003 common period. It is important to note that samples sent to NOSAMS for ${ }^{14} \mathrm{C}$ analysis were dated by means of visual crossdating and skeleton plots. Ring-width measurements were taken afterward to describe the agreement between ring patterns within and between sections in a numerical form. Because of the limited number of available tree-ring series, a master sagebrush chronology (with its associated statistics, such as mean sensitivity) was not computed.

\section{Geochemical Analysis}

Geochemical and AMS ${ }^{14} \mathrm{C}$ analyses were performed at the National Ocean Sciences AMS (NOSAMS) facility at Woods Hole Oceanographic Institution. Any inorganic carbon, as well as any mobile humic and fulvic substances, were first removed from the samples, then carbon dioxide was generated by combustion and reacted with a catalyst to form graphite using an $\mathrm{Fe} / \mathrm{H}_{2}$ catalyticreduction. Graphite was pressed into targets, which were analyzed on the accelerator along with standards and process blanks. Two primary standards were used during all ${ }^{14} \mathrm{C}$ measurements: NBS oxalic acid I (NIST-SRM-4990) and oxalic acid II (NIST-SRM-4990C). The ${ }^{14} \mathrm{C}$ activity ratio of oxalic acid II $\left(\delta^{13} \mathrm{C}=-17.3 \%\right.$ ) to oxalic acid I $\left(\delta^{13} \mathrm{C}=-19.0 \%\right.$ ) was taken to be 1.293 . Every group of samples processed included an appropriate blank, namely a Johnson-Mathey $99.9999 \%$ graphite powder, which was analyzed concurrently with the group.

${ }^{14} \mathrm{C}$ amounts are given using the fraction modern $\left(\mathrm{F}_{\mathrm{m}}\right)$ notation. $\mathrm{F}_{\mathrm{m}}$ is a measurement of the deviation of the ${ }^{14} \mathrm{C} /{ }^{12} \mathrm{C}$ ratio of a sample from $95 \%$ of the ${ }^{14} \mathrm{C}$ concentration in AD 1950 of NBS oxalic acid I normalized to $\delta^{13} \mathrm{C}_{\mathrm{VPDB}}=-19 \%$ (Olsson 1970). AMS results are calculated using the internation- 
ally accepted modern value of $1.176 \pm 0.010 \times 10^{-12}$ (Karlén et al. 1968), and a final ${ }^{13} \mathrm{C}$ correction is made to normalize the sample $\mathrm{F}_{\mathrm{m}}$ to a $\delta^{13} \mathrm{C}_{\mathrm{VPDB}}$ value of $-25 \%$. Stable isotope measurements of sample $\delta^{13} \mathrm{C}$ used to correct $\mathrm{F}_{\mathrm{m}}$ values were made with either a VG PRISM or VG OPTIMA mass spectrometer by analyzing subsamples of the $\mathrm{CO}_{2}$ gas generated during graphite production. Because the AMS method directly counts the number of ${ }^{14} \mathrm{C}$ atoms contained in a sample, internal statistical errors were calculated using the number of counts measured from each target. An external error was calculated from the reproducibility of individual analyses for a given target. The reported $F_{m}$ error was the larger of the internal or external errors. Measurements of $F_{m}$ were compared with their expected values from 1950 to 1992, using the same reference curve used by Biondi and Fessenden (1999), which was based on a personal communication by JR Southon, Lawrence Livermore National Laboratory, Center for AMS.

\section{RESULTS AND DISCUSSION}

Cross-sections had a typical lobate form (Figure 2) because of the cleft and irregular stem that is characteristic of big sagebrush, especially in older plants (Ferguson 1964). Hence, rings were mostly discontinuous and eccentric, and their absolute width varied along the section. However, the relative width of each ring, i.e. when compared to adjacent ones, was largely constant around the stem. This made crossdating possible, since skeleton plots are based on relative ring width (Stokes and Smiley 1996). Ring color (along with other anatomical characteristics) was also a shared trait within a section, hence useful in visual crossdating. The greatest change in color occurred between heartwood and sapwood, which was considerably lighter and consisted of the current and prior year growth layers (Ferguson 1964). Even though samples were collected on 16 June 2005, the growth layer for that year was usually as large as the 2004 one, indicating either a very favorable year or a growing season that ends early in the summer. No locally absent or false rings were identified in the samples.

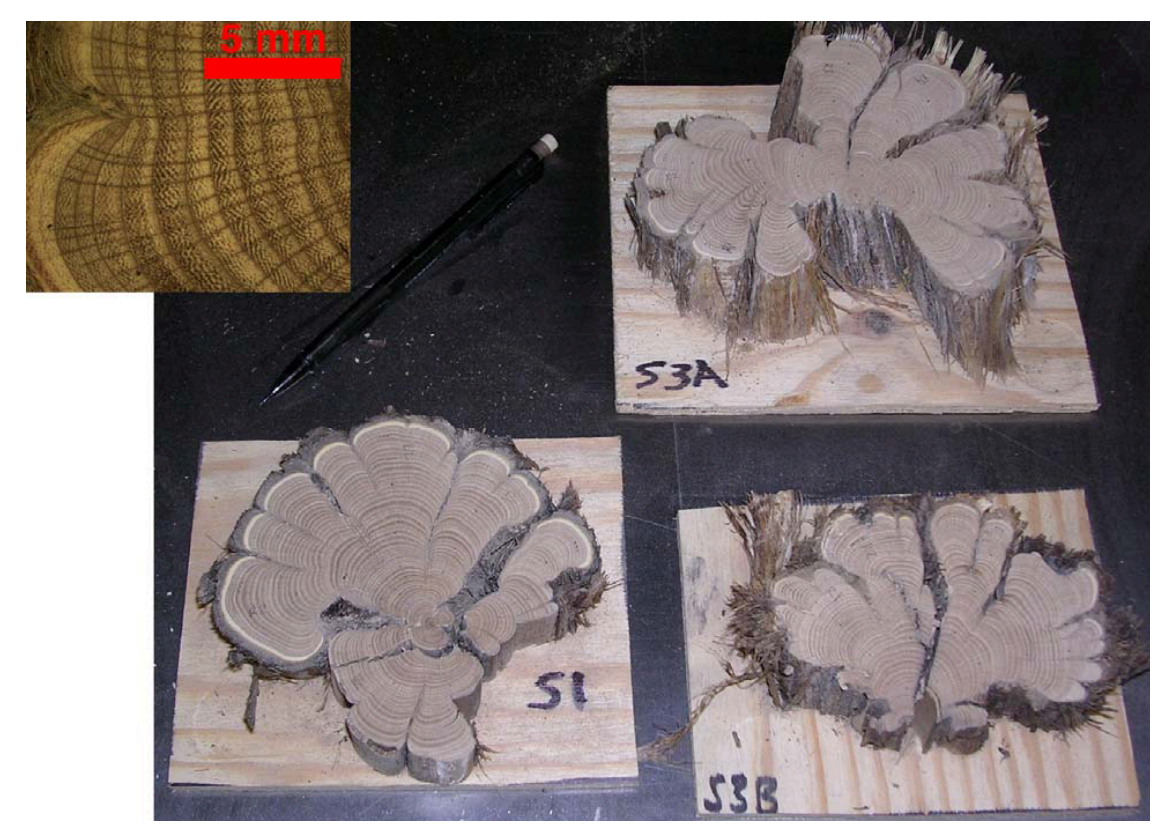

Figure 2 Sagebrush sections (S1, S3A, and S3B) that were used to sample rings for ${ }^{14} \mathrm{C}$ analysis. The lobate form of the cross-sections is clearly visible, and a mechanical pencil is shown for scale. Inset: Wood features of a lobe of S3A, including the individual layers (with a 5-mm line for scale), the separation between heartwood and sapwood (whose color is much lighter) and the bark. 
The number of rings on each section did not exceed 60 , and the ring patterns were relatively uniform, but it was still possible to crossdate growth rings within a sample and across samples. Growth rings were analyzed on more than 1 radius per section (Table 1), and a composite skeleton plot could be made for each section. The 4 composites could then be combined into a site skeleton plot, which matched the skeleton plot version of a Pinus monophylla chronology developed at a site located about $50 \mathrm{~km}$ away (F Biondi, unpublished data). Agreement between ring patterns in big sagebrush and nearby conifers was also reported by Ferguson (1964).

Table 1 Crossdating results for the big sagebrush sections $(\mathrm{n} / \mathrm{a}=$ not available).

\begin{tabular}{|c|c|c|c|c|c|c|c|c|c|}
\hline & \multirow[b]{2}{*}{ Section } & \multirow[b]{2}{*}{ Radii } & \multirow{2}{*}{$\begin{array}{l}\text { Max \# } \\
\text { of rings }^{\mathrm{a}}\end{array}$} & \multicolumn{3}{|c|}{ Ring width (mm) } & \multirow{2}{*}{$\begin{array}{l}\text { Mean } r \\
\text { value }^{\mathrm{b}}\end{array}$} & \multirow{2}{*}{$\begin{array}{l}\text { Baillie-Pilcher } \\
t \text { value }^{\mathrm{b}}\end{array}$} & \multirow[b]{2}{*}{$\mathrm{GLK}^{\mathrm{b}}$} \\
\hline & & & & Mean \pm SD & Min & Max & & & \\
\hline & 1 & 5 & 59 & $1.02 \pm 0.46$ & 0.20 & 2.30 & 0.85 & 12.4 & 85.1 \\
\hline & 2 & 2 & 32 & $1.95 \pm 0.81$ & 0.80 & 4.22 & $\mathrm{n} / \mathrm{a}$ & $\mathrm{n} / \mathrm{a}$ & $\mathrm{n} / \mathrm{a}$ \\
\hline & $3 \mathrm{~A}^{\mathrm{c}}$ & 5 & 58 & $1.22 \pm 0.55$ & 0.26 & 3.01 & 0.76 & 4.5 & 72.0 \\
\hline & $3 \mathrm{~B}^{\mathrm{c}}$ & 4 & 56 & $1.19 \pm 0.47$ & 0.43 & 2.67 & 0.81 & 5.5 & 71.1 \\
\hline Site value & 4 & 16 & 59 & $1.21 \pm 0.58$ & 0.20 & 4.22 & 0.53 & 3.9 & 67.7 \\
\hline
\end{tabular}

Years assigned to individual wood layers aligned with their expected ${ }^{14} \mathrm{C}$ values, matching the location of the ${ }^{14} \mathrm{C}$ peak (Figure 3). The maximum error reported for the $\mathrm{F}_{\mathrm{m}}$ measurements was less than $0.6 \%$ of the measured value (Table 2), and therefore negligible compared to the differences between years. Given the clear boundaries of wood increments in big sagebrush, the limited number of ${ }^{14} \mathrm{C}$ dates ( 5 from each of 2 sections) was adequate to answer the research question.

Table 2 AMS ${ }^{14} \mathrm{C}$ measurements on Artemisia tridentata sections (see Figure 3).

\begin{tabular}{lllllll}
\hline $\begin{array}{l}\text { DendroLab } \\
\text { sample ID }\end{array}$ & $\begin{array}{l}\text { Section } \\
\mathrm{nr}\end{array}$ & $\begin{array}{l}\text { Estimated } \\
\mathrm{yr}^{\mathrm{b}}\end{array}$ & $\begin{array}{l}\text { Dryy } \\
\text { weight }(\mathrm{g})\end{array}$ & $\begin{array}{l}\text { NOSAMS } \\
\text { lab } \mathrm{nr}\end{array}$ & $\begin{array}{l}\text { Fraction } \\
\text { modern }\left(\mathrm{F}_{\mathrm{m}}\right)^{\mathrm{d}}\end{array}$ & $\mathrm{F}_{\mathrm{m}}$ error $^{\mathrm{d}}$ \\
\hline SB1 & 1 & 1955 & 0.80 & OS-54404 & 1.0155 & 0.0035 \\
SB2 & 3 & 1955 & 0.67 & OS-54405 & 1.0176 & 0.0049 \\
SB3 & 1 & 1975 & 1.22 & OS-54406 & 1.4072 & 0.0046 \\
SB4 & 3 & 1975 & 1.10 & OS-54407 & 1.4224 & 0.0053 \\
SB5 & 1 & 1962 & 0.92 & OS-54408 & 1.4291 & 0.0046 \\
SB6 & 3 & 1962 & 1.09 & OS-54498 & 1.3755 & 0.0052 \\
SB7 & 1 & 1966 & 1.00 & OS-54668 & 1.7340 & 0.0066 \\
SB8 & 3 & 1966 & 1.09 & OS-54409 & 1.7268 & 0.0075 \\
SB9 & 1 & 1964 & 1.23 & OS-54410 & 1.9223 & 0.0061 \\
SB10 & 3 & 1964 & 1.09 & OS-54570 & 1.8672 & 0.0112 \\
\hline
\end{tabular}

${ }^{\mathrm{a}}$ This is the only information on each sample that was sent to the NOSAMS facility, so ${ }^{14} \mathrm{C}$ results would not be influenced by crossdating results.

${ }^{b}$ Year of formation, determined by visually crossdating growth rings of 4 sagebrush sections.

${ }^{\mathrm{c}}$ The samples were air-dried.

${ }^{\mathrm{d}}$ This represents the amount of ${ }^{14} \mathrm{C}$ in the sample. See text for details.

Based on ring-width measurements (Table 1), annual growth increment averaged about $1.2 \mathrm{~mm}$ with a standard deviation of about $0.6 \mathrm{~mm}$; the smallest width was $0.2 \mathrm{~mm}$. Section 2 had larger rings 


\section{AMS Radiocarbon Results}

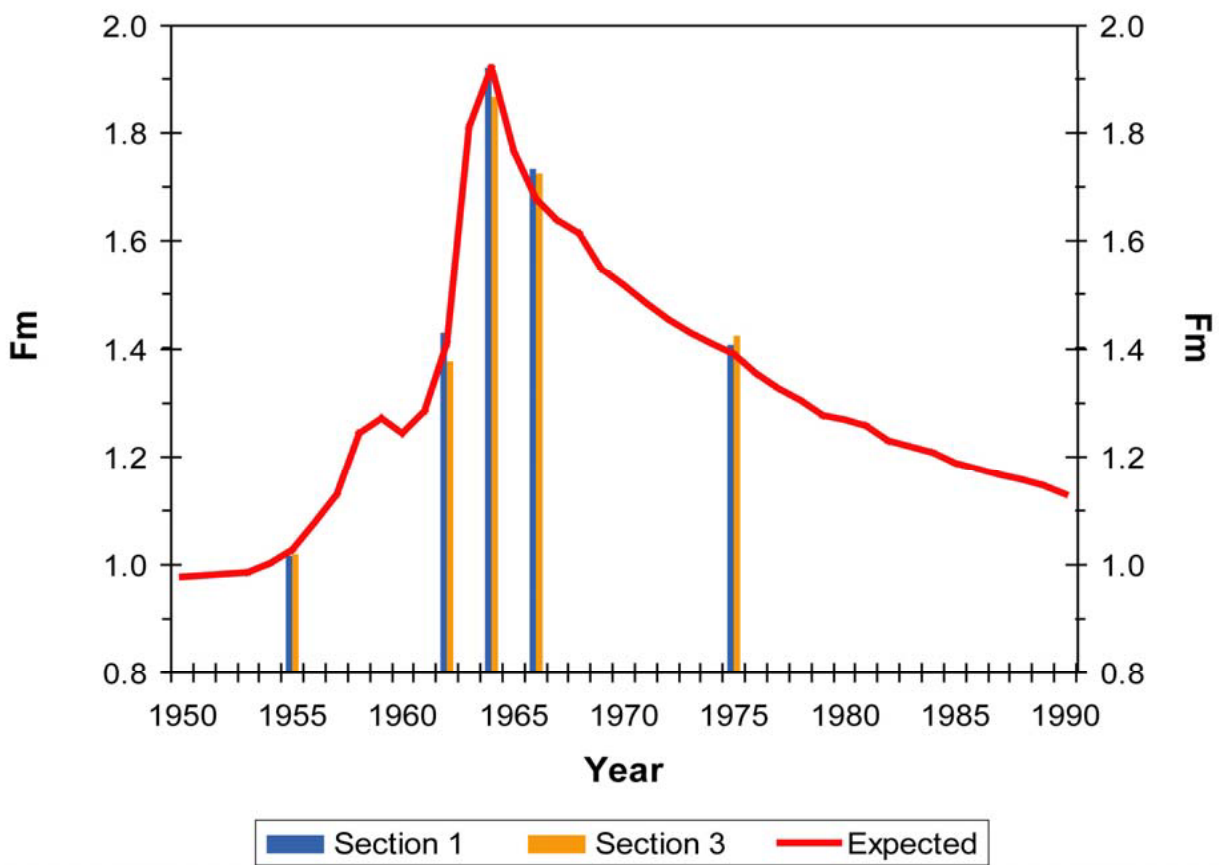

Figure $3{ }^{14} \mathrm{C}$ amounts (bars) measured in 10 samples from 2 Artemisia tridentata cross-sections, and compared to their expected values (line) from 1950 to $1992 . \mathrm{Fm}=$ fraction modern (see text for details).

(mean of $2.0 \mathrm{~mm}$ ), including the widest one of all $(4.2 \mathrm{~mm})$, and was considerably younger than the others (Table 1). Since it did not crossdate well and it did not extend to the 1950s, it was not used for ${ }^{14} \mathrm{C}$ analysis. Overall, no radius included more than 59 rings, mean series length was $51 \mathrm{yr}$, and the average COFECHA (Grissino-Mayer 2001) correlation of the 16 series with the master chronology was 0.6 . The average of all pairwise correlations between un-transformed ring-width series $\geq 48$ yr was 0.5 , and the within-section correlations were higher (about 0.8; Table 1). The first principal component of the ring-width measurements from 1956 to 2003 on 13 radii accounted for $52.5 \%$ of the variance. The second and third principal component accounted for another 25 and $11 \%$, respectively, and their eigenvectors separated radii according to the sections to which they belonged. Baillie-Pilcher's $t$ values and GLK coefficients suggested moderate crossdating quality (except for Section 1; Table 1), most likely because of the short length and relative uniformity of ring-width series.

We crossdated a minimal number of samples, i.e. 16 series from 3 separate individuals. Since the area where the sections were collected had flat topography and relatively deep soils, site conditions most likely allowed big sagebrush to grow relatively large rings. In more difficult conditions, i.e. in steep terrain and/or thinner soil layers as well as at higher or lower elevations, crossdating is not guaranteed (Ferguson 1964). With regard to the cause of crossdating, Ferguson (1964) suggested that moisture, especially during the winter, is the main climatic driver for synchronous growth patterns in big sagebrush. On the other hand, a positive growth response to warming was demonstrated for big sagebrush growing at high elevation $(2920 \mathrm{~m}$ ) in Colorado (Perfors et al. 2003). While precipitation patterns influenced recruitment of big sagebrush in Wyoming, this relationship varied 
with subspecies (Maier et al. 2001), and population dynamics appeared to be controlled by several climatic factors in southern British Columbia (Cawker 1980).

\section{CONCLUSION}

In shrublands, historical records of landscape changes are limited, and this restricts our ability to reconstruct, model, and predict vegetation shifts linked to disturbance, climate, and their interaction. In modern times, exotic annual plants such as cheatgrass (Bromus tectorum L.) have heavily invaded Great Basin rangelands, creating conditions for frequent and widespread wildfires, and changing successional pathways such that fire no longer returns pinyon-juniper woodland to sagebrush grassland (Brooks et al. 2003). As fire suppression policies are being established and restoration programs are designed to mitigate the direct and indirect impacts of fires in the Great Basin, it is important to have a detailed long-range understanding of the timing and possible causes of past fires that have influenced species composition and community structure in shrub-grass habitats. Our results, obtained by ${ }^{14} \mathrm{C}$ dating, independently confirm the annual nature of growth rings in big sagebrush. This finding opens the door to the development of spatially explicit, well-replicated, proxy records of environmental change in Great Basin valleys.

\section{ACKNOWLEDGMENTS}

F Biondi and S Strachan were partially supported by the National Science Foundation (NSF) under Grant ATM-CAREER-0132631. Funding for ${ }^{14} \mathrm{C}$ analyses was provided by the NOSAMS Research Initiatives Program. The NOSAMS facility was supported by NSF Cooperative Agreement OCE9807266. The comments of an anonymous reviewer helped improve an earlier version of the manuscript.

\section{REFERENCES}

Baillie MGL, Pilcher JR. 1973. A simple crossdating program for tree-ring research. Tree-Ring Bulletin 33: 7-14.

Baker WL, Shinneman DJ. 2004. Fire and restoration of piñon-juniper woodlands in the western United States: a review. Forest Ecology and Management 189(1-3): $1-21$.

Biondi F, Fessenden JE. 1999. Radiocarbon analysis of Pinus lagunae tree rings: implications for tropical dendrochronology. Radiocarbon 41(3):241-9.

Blackburn WH, Tueller PT. 1970. Pinyon and juniper invasion in black sagebrush communities in east-central Nevada. Ecology 51(5):841-8.

Bowman S. 1990. Radiocarbon Dating. Berkeley: University of California Press. 64 p.

Brooks ML, D'Antonio CM, Richardson DM, Grace JB, Keeley JE, DiTomaso JM, Hobbs RJ, Pellant M, Pyke D. 2003. Fire regimes and potential for ecosystem recovery after plant invasions. In: Pirosko C, editor. Proceedings of the California Invasive Plant Council Symposium. Volume 7. Berkeley: California Invasive Plant Council. p 21.

Burkhardt JW, Tisdale EW. 1976. Causes of juniper invasion in southwestern Idaho. Ecology 57(3):472-84.

Cawker KB. 1980. Evidence of climatic control from population age structure of Artemisia tridentata Nutt. in southern British Columbia. Journal of Biogeography 7(3):237-48.

Cronquist A, Holmgren A, Holgren N, Reveal J, Holmgren P. 1994. Intermountain Flora: Vascular Plants of the Intermountain West, USA. New York: New York Botanical Garden. 446 p.

Dezzeo N, Worbes M, Ishii I, Herrera R. 2003. Annual tree rings revealed by radiocarbon dating in seasonally flooded forest of the Mapire River, a tributary of the lower Orinoco River, Venezuela. Plant Ecology 168(1):165-75

Diettert RA. 1938. The morphology of Artemisia tridentata Nutt. Lloydia 1:3-74.

Eckstein D, Bauch J. 1969. Beitrag zur rationalisierung eines dendrochronologischen verfahrens und zur analyse seiner aussagesicherheit. Forstwissenschaftliches Centralblatt 88:230-50. In German.

Egan D, Howell EA, editors. 2001. The Historical Ecology Handbook: A Restorationist's Guide to Reference Ecosystems. Washington, DC: Island Press. 469 p.

Ferguson CW. 1964. Annual Rings in Big Sagebrush: Artemisia tridentata. Papers of the Laboratory of TreeRing Research, No. 1. Tucson: University of Arizona Press. 95 p.

Floyd ML, Romme WH, Hanna DD. 2000. Fire history and vegetation pattern in Mesa Verde National Park, 
Colorado, USA. Ecological Applications 10(6):166680.

Frantz BR, Kashgarian M, Coale KH, Foster MS. 2000. Growth rate and potential climate record from a rhodolith using ${ }^{14} \mathrm{C}$ accelerator mass spectrometry. Limnology and Oceanography 45(8):1773-7.

Grissino-Mayer HD. 1997. Computer assisted, independent observer verification of tree-ring measurements. Tree-Ring Bulletin 54:29-41.

Grissino-Mayer HD. 2001. Evaluating crossdating accuracy: a manual and tutorial for the computer program COFECHA. Tree-Ring Research 57(2):205-21.

Gruell GE. 1999. Historical and modern roles of fire in pinyon-juniper. In: Monsen SB, Stevens R, editors. Proceedings: Ecology and Management of PinyonJuniper Communities within the Interior West. Proceedings RMRS-P-9. USDA, Forest Service, Rocky Mountain Research Station, Ogden, Utah. p 24-8.

Holmes RL. 1983. Computer-assisted quality control in tree-ring dating and measurement. Tree-Ring Bulletin 43:69-78.

Horvitz CC, Sternberg LDSLOR. 1999. ${ }^{14} \mathrm{C}$ dating of tree falls on Barro Colorado Island (Panama): a new method to study tropical rain forest gap dynamics. Journal of Tropical Ecology 15(6):723-35.

Houston DB. 1973. Wildfires in northern Yellowstone National Park. Ecology 54(5):1111-7.

Hua Q, Barbetti M. 2004. Review of tropospheric bomb ${ }^{14} \mathrm{C}$ data for carbon cycle modeling and age calibration purposes. Radiocarbon 46(3):1273-98.

Jolliffe IT. 1986. Principal Component Analysis. (Springer Series in Statistics). New York: Springer. $271 \mathrm{p}$.

Karlén I, Olsson IU, Kallberg P, Kilicci S. 1968. Absolute determination of the activity of two ${ }^{14} \mathrm{C}$ dating standards. Arkiv för Geofysik 4:465-71.

Little Jr EL. 1976. Atlas of United States Trees. Volume 3: Minor Western Hardwoods. Miscellaneous Publication 1314, US Department of Agriculture. Washington, DC: United States Government Printing Office. $290 \mathrm{p}$.

Maier AM, Perryman BL, Olson RA, Hild AL. 2001. Climatic influences on recruitment of 3 subspecies of $A r$ temisia tridentata. Journal of Range Management 54(6):699-703.

Mensing SA, Livingston S, Barker P. 2006. Long-term fire history in Great Basin sagebrush reconstructed from macroscopic charcoal in spring sediments, Newark Valley, Nevada. Western North American Naturalist 66:64-77.

Miller RF, Rose JA. 1999. Fire history and western juniper encroachment in sagebrush steppe. Journal of Range Management 52(6):550-9.

Miller RF, Tausch RJ. 2001. The role of fire in juniper and pinyon woodlands: a descriptive analysis. In: Galley KEM, Wilson TP, editors. Proceedings of the Invasive Species Workshop: The Role of Fire in the Con- trol and Spread of Invasive Species. Miscellaneous Publication No. 11. Tallahassee, Florida, USA: Tall Timbers Research Station. p 15-30.

Olsson IU. 1970. The use of oxalic acid as a standard. In: Olsson IU, editor. Radiocarbon Variations and Absolute Chronology. Nobel Symposium, 12th Proceedings. New York: John Wiley and Sons. p 17.

Paysen TE, Ansley RJ, Brown JK, Gottfried GJ, Haase SM, Harrington MG, Narog MG, Sackett SS, Wilson RC. 2000. Fire in western shrubland, woodland and grassland ecosystems. In: Brown JK, Smith JK, editors. Wildland Fire in Ecosystems: Effects of Fire on Flora. Volume 2. USDA Forest Service General Technical Report RMRS-GTR-42. p 121-59.

Perfors T, Harte J, Alter SE. 2003. Enhanced growth of sagebrush (Artemisia tridentata) in response to manipulated ecosystem warming. Global Change Biology 9(5):736-42.

Perryman BL, Olson RA. 2000. Age-stem diameter relationships of big sagebrush and their management implications. Journal of Range Management 53(3):3426.

Perryman BL, Maier AM, Hild AL, Olson RA. 2001. Demographic characteristics of 3 Artemisia tridentata Nutt. subspecies. Journal of Range Management 54(2): 166-70.

Poussart PF, Evans MN, Schrag DP. 2004. Resolving seasonality in tropical trees: multi-decade, high-resolution oxygen and carbon isotopic records from Indonesia and Thailand. Earth and Planetary Science Letters 218(3-4):301-16.

Rowell R, editor. 1984. The Chemistry of Solid Wood. Washington, DC: American Chemical Society. 614 p.

Shumar ML, Anderson JE, Reynolds TD. 1982. Identification of subspecies of big sagebrush by ultraviolet spectrophotometry. Journal of Range Management 35(1):60-2.

Stokes MA, Smiley TL. 1996. An Introduction to TreeRing Dating. Tucson: University of Arizona Press. $73 \mathrm{p}$.

Swetnam TW, Allen CD, Betancourt JL. 1999. Applied historical ecology: using the past to manage for the future. Ecological Applications 9(4):1189-206.

Wambolt CL, Frisina MR. 2002. Montana sagebrush guide. Helena, Montana, USA: Montana Department of Fish, Wildlife and Parks. $71 \mathrm{p}$.

West NE, Young JA. 2000. Intermountain valleys and lower mountain slopes. In: Barbour MG, Billings WD, editors. North American Terrestrial Vegetation. 2nd edition. Cambridge: Cambridge University Press. p 255-84.

West NE, Tausch RJ, Rea KH, Tueller PT. 1978. Taxonomic determination, distribution, and ecological indicator values of sagebrush within the pinyon-juniper woodlands of the Great Basin. Journal of Range Management 31(2):87-92.

Westerling AL, Gershunov A, Brown TJ, Cayan DR, 
Dettinger MD. 2003. Climate and wildfire in the western United States. Bulletin of the American Meteorological Society 84(5):595-604.

Westerling AL, Hidalgo HG, Cayan DR, Swetnam TW. 2006. Warming and earlier spring increase western US forest wildfire activity. Science 313(5789):940-3.

Wigley TML, Briffa KR, Jones PD. 1984. On the average value of correlated time series, with applications in dendroclimatology and hydrometeorology. Journal of Climate and Applied Meteorology 23(2):201-13.
Wisdom MJ, Rowland MM, Suring LH, Schueck L, Wolff Meinke C, Wales BC, Knick ST. 2003. Procedures for regional assessment of habitats for species of conservation concern in the sagebrush ecosystem. March 2003 Report, Version 1, Pacific Northwest Research Station, 1401 Gekeler Lane, La Grande, Oregon 97850 , USA.

Worbes M, Junk WJ. 1989. Dating tropical trees by means of ${ }^{14} \mathrm{C}$ from bomb tests. Ecology 70(2):503-7. 